\title{
Władza publiczna a system opieki zdrowotnej
}

\section{Charakter prawny polskiego systemu opieki zdrowotnej}

Oharakter prawny polskiego systemu opieki zdrowotnej był już przedmiotem opracowań, w których zauważono, że całość relacji pomiędzy podmiotami systemu opieki zdrowotnej ma szczególny charakter. Wbrew stosowanej terminologii system „ubezpieczenia zdrowotnego" w Narodowym Funduszu Zdrowia nie jest z pewnością systemem ubezpieczeniowym $\mathrm{w}$ tradycyjnym (bismarckowskim) rozumieniu tego pojęcia, przede wszystkim z uwagi na okoliczność, że NFZ nie jest w żadnym stopniu zobowiązany do świadczeń na rzecz ubezpieczonych, będąc jedynie zarządcą środków pochodzących ze składek i organizatorem systemu poprzez zawieranie umów o udzielanie świadczeń opieki zdrowotnej. Z drugiej strony Fundusz nie jest także organem administracji publicznej w rozumieniu ustrojowym i nie ma generalnie kompetencji do stosowania środków prawnych, właściwych organom administracji publicznej, gdyż analiza kompetencji szczegółowo określonych $\mathrm{w}$ wielu przepisach ustawy nie pozwala dostrzec jego uprawnień władczych. $Z$ tego względu sformułowano tezę, że w polskim systemie opieki zdrowotnej urzeczywistniana jest nowa technika realizacji idei zabezpieczenia społecznego - technika powiernicza ${ }^{1}$.

Jako jej aksjologiczne uzasadnienie przywołać należy koncepcję państwa gwarantującego, posługującego się, między innymi, instrumentem prywatyzacji zadań publicznych, czyli powierzania zadań (lub tylko ich

* Dr hab. prof. nadzw., Katedra Prawa Pracy i Prawa Socjalnego, Wydział Prawa i Administracji Uniwersytetu im. Adama Mickiewicza w Poznaniu.

${ }_{1}$ Por. D.E. Lach, Powiernicza technika realizacji zabezpieczenia społecznego (na przykładzie ubezpieczenia zdrowotnego), „Państwo i Prawo” 2009, nr 3; idem, Prawny paradygmat opieki zdrowotnej a stosunek "ubezpieczenia zdrowotnego" i jego charakter prawny, [w:] Z. Kubot, T. Kuczyński (red.), Z zagadnień prawa pracy i prawa socjalnego. Księga jubileuszowa Profesora Herberta Szurgacza, Wrocław 2011. 
wykonywania) podmiotom niepublicznym, które realizują je metodami prywatnoprawnymi. Obserwowany, przede wszystkim w odniesieniu do zadań publicznych z zakresu zabezpieczenia społecznego ${ }^{2}$, "odwrót w zakresie zaangażowania państwa (jego aparatu) w realizację zabezpieczenia społecznego i włączanie $\mathrm{w}$ tę dziedzinę $\mathrm{w}$ coraz szerszym zakresie podmiotów niepublicznych"3 motywowany jest rozmaitymi względami. Z jednej strony chodzi o kwestię zoptymalizowania realizacji tych zadań, z drugiej oczywiście o wyeliminowanie ryzyka, że obywatele lub inne podmioty będą konstruować (dochodzić) roszczenia o świadczenia lub ich rozliczenie w stosunku do fiskusa ${ }^{5}$. Nie bez znaczenia jest jednak także pewien klimat polityczny i społeczny - prawo nie jest bowiem ani tworzone, ani stosowane w próżni. Po 45 latach PRL zrozumiała może być awersja wobec wizji omnipotentnego państwa (co oczywiście nie wyklucza tęsknoty za paternalistyczną opieką). Pamiętać też należy, że początek lat dziewięćdziesiątych wieku XX to okres, w którym neoliberalistyczna ideologia miała wielką siłę oddziaływania, widoczną w dążeniu do prywatyzacji (zarówno tej majątkowej, jak i rozumianej jako zmiana metody regulacji i odejście od władczych publicznoprawnych środków działania na rzecz metod prywatnoprawnych), a także w niewzruszonej wierze w działanie mechanizmów rynkowych.

W tym kontekście trzeba przypomnieć, że podczas prac Okragłego Stołu podnoszono również kwestie związane z reformą systemu ochrony zdrowia i opieki zdrowotnej. W protokole końcowym obie strony zgodziły się nie tylko co do konieczności radykalnej reformy systemu, ale także co do głównych zarysów jego przyszłego kształtu. Stwierdzono, że finansowanie systemu powinno opierać się na składkach ubezpieczeniowych,

${ }^{2}$ Por. D.E. Lach, Powierzanie realizacji zadań publicznych z zakresu zabezpieczenia społecznego podmiotom niepublicznym, „Państwo i Prawo” 2015, nr 2.

${ }_{3}$ Tak H. Szurgacz, Zagadnienie przekazywania przez państwo zadań w zakresie zabezpieczenia społecznego podmiotom niepublicznym, [w:] idem (red.), Konstytucyjne problemy prawa pracy i zabezpieczenia społecznego. Referaty na XV Zjazd Katedr i Zakładów Prawa Pracy i Ubezpieczeń Społecznych, Wrocław 1-2 czerwca 2005 r., Wrocław 2005, s. 131-132.

${ }^{4}$ S. Biernat (Prywatyzacja zadań publicznych. Problematyka prawna, Warszawa-Kraków 1994, s. 7 i nast.) wskazywał np. na ograniczone możliwości materialne, kadrowe czy też techniczne administracji publicznej wobec rosnących wymagań obywateli, wyższą (na ogół) efektywność podmiotów niepublicznych, dotyczącą nie tylko kosztów, ale i jakości świadczeń oraz „nową wizję państwa i społeczeństwa”, a także „chęć rozdzielenia politycznych funkcji państwa od jego funkcji gospodarczych", natomiast A. Doliwa (Ustawowe powiernictwo wykonywania własności państwowej na przykładzie Agencji Własności Rolnej Skarbu Państwa, „Studnia Prawnicze” 2003, nr 1, s. 111) przywoływał zamiar odbiurokratyzowania administracji w procesie zarządzania własnością publiczną, obniżenie kosztów oraz usprawnienie zarządu, a także oddzielenie praktycznej działalności gospodarczej od polityki.

${ }^{5}$ Tak J. Jończyk, Prawo zabezpieczenia społecznego, Kraków 2001, s. 111-112. 
zróżnicowanych terytorialnie i obciążających przedsiębiorców oraz pracodawców, lecz nie pracowników, równocześnie jednak podkreślono, że tytuł do świadczeń winien mieć "charakter zaopatrzeniowy" ${ }^{\prime 6}$. Innymi słowy próbowano, utrzymując szeroki zakres podmiotowy systemu, obejmujący obecnie właściwie wszystkich rezydentów (por. art. 2 ustawy z 27 sierpnia 2004 r. o świadczeniach opieki zdrowotnej finansowanych ze środków publicznych ${ }^{7}$, dalej jako u.ś.o.z.), zmienić zasadniczo jego metodę finansowania na składkową.

Warto także zauważyć, że system "ubezpieczenia zdrowotnego", od uchwalenia pierwszej ustawy z 6 lutego 1997 r. o powszechnym ubezpieczeniu zdrowotnym, był nie tylko wielokrotnie, ale i zasadniczo przebudowywany ${ }^{8}$. Abstrahując od omówienia tej ewolucji i jej etapów („odmian” czy też „wersji” systemu) w kontekście niniejszego opracowania można jednak zauważyć jeden istotny aspekt: w każdej kolejnej wersji rosło znaczenie i rola władzy publicznej w funkcjonowaniu systemu opieki zdrowotnej. Milowym krokiem była oczywiście rezygnacja z wojewódzkich kas chorych na rzecz Narodowego Funduszu Zdrowia. I o ile trudno sobie dziś wyobrazić cofnięcie zmian po stronie świadczeniodawców (likwidacja państwowej służby zdrowia jako sektora administracji świadczącej i powołanie do życia Zakładów Opieki Zdrowotnej (1991), obecnie podmiotów leczniczych, działających samodzielnie w ramach prowadzonej, w różnych formach, działalności gospodarczej), o tyle z punktu widzenia organizacji systemu opieki zdrowotnej można zadawać sobie pytanie, czy - w bliższej lub dalszej przyszłości - funkcje władzy publicznej nie zyskają na znaczeniu.

${ }^{6}$ Pojęcie to nie zostało jednak skonkretyzowane. W.C. Włodarczyk komentuje, że akceptacja ubezpieczeniowej - składkowej metody finansowania w połączeniu z "zaopatrzeniowym" tytułem do świadczeń świadczy o koncepcyjnym pęknięciu, utrudniającym późniejsze prace. W.C. Włodarczyk, Reforma opieki zdrowotnej w Polsce. Studium polityki zdrowotnej, Kraków 1998, s. 152.

7 T.j. DzU, 2008, nr 164, poz. 1027 ze zm.

${ }^{8}$ Na ten temat por. J. Jończyk, Ubezpieczenie zdrowotne, „Praca i Zabezpieczenie Społeczne" 2003, nr 4, s. 3 i nast.; idem, Czwarta wersja powszechnego ubezpieczenia zdrowotnego, „Praca i Zabezpieczenie Społeczne” 2004, nr 11, s. 2 i nast., gdzie autor wyróżnia następujące modyfikacje powszechnego ubezpieczenia zdrowotnego: korporacyjno-przedstawicielską (pod rządami ustawy z 6.02.1997 o powszechnym ubezpieczeniu zdrowotnym, DzU, 1997, nr 28, poz. 153), która nie zdążyła wejść w życie; samorządową wprowadzoną jeszcze przed wejściem pierwotnej ustawy o powszechnym ubezpieczeniu zdrowotnym w życie 1.01.1999 ustawą z dnia 18.07.1998 r. o zmianie ustawy o powszechnym ubezpieczeniu zdrowotnym oraz o zmianie niektórych ustaw (DzU, 1998, nr 117, poz. 756) i narodowa, w ramach ustawy z dnia 23.01.2003 o powszechnym ubezpieczeniu w Narodowym Funduszu Zdrowia (DzU, 2003, nr 45, poz. 391). Ten katalog wypada uzupełnić o wersję czwarta, w ramach ustawy z dnia 27.08.004 r., o świadczeniach opieki zdrowotnej finansowanych ze środków publicznych. 


\section{Zadania i rola władz publicznych}

Ustawa o świadczeniach opieki zdrowotnej finansowanych ze środków publicznych $\mathrm{w}$ rozdziale 2 zatytułowanym Zadania władz publicznych szczegółowo określa zadania władzy wykonawczej w zakresie zapewnienia równego dostępu do świadczeń opieki zdrowotnej ${ }^{9}$. Przepis art. 6 u.ś.o.z. ogólnie opisuje w otwartym katalogu najważniejsze zadania, wskazując na:

1) tworzenie warunków funkcjonowania systemu ochrony zdrowia,

2) analizę i ocenę potrzeb zdrowotnych oraz czynników powodujących ich zmiany,

3) promocję zdrowia i profilaktykę, mające na celu tworzenie warunków sprzyjających zdrowiu - oraz

4) finansowanie w trybie i na zasadach określonych ustawą świadczeń opieki zdrowotnej.

Dalsze przepisy ustawy uszczegóławiają ten katalog w odniesieniu do kolejnych organów władzy publicznej - samorządowej (gmina, powiat, samorząd województwa, w rozbiciu na zadania własne i zlecone) i rządowej (wojewoda, minister właściwy do spraw zdrowia i minister właściwy do spraw finansów publicznych). Są to przede wszystkim działania dotyczące monitorowania potrzeb i stopnia ich zaspokajania, analizowania istniejącej sytuacji zdrowotnej, wpływania na zachowania świadczeniobiorców. Gdy idzie natomiast o administrację rządowa, to jej organom przysługują uprawnienia z zakresu oceny zabezpieczenia opieki zdrowotnej i stopnia realizacji zadań powierzonych samorządowi terytorialnemu. Najkrócej rzecz ujmując - władzę publiczną obciążają zadania dwojakiego rodzaju. Po pierwsze - w nawiązaniu do koncepcji państwa gwarantującego - są to zadania służące dynamicznemu nadzorowi. Po drugie natomiast - uwzględniając powszechność systemu oraz szczególny charakter niektórych świadczeń opieki zdrowotnej -finansowanie określonych ustawą świadczeń opieki zdrowotnej.

${ }^{9} \mathrm{~W}$ literaturze trafnie podniesiono, że grupa przepisów zawarta $\mathrm{w}$ tym rozdziale jest nowością w stosunku do poprzednio obowiązujących ustaw regulujących organizację i funkcjonowanie systemu opieki zdrowotnej, a umieszczenie tych przepisów w ustawie o świadczeniach opieki zdrowotnej finansowanych ze środków publicznych jest konsekwencją wyroku TK z dnia 7 stycznia 2004 r., K 14/03. Por. K. Baka, G. Machulak, A. Pietraszewska-Macheta, A. Sidorko, Ustawa o świadczeniach opieki zdrowotnej finansowanych ze środków publicznych. Komentarz, Warszawa 2010, komentarz do art. 6, pkt 2 . 


\section{Zakres podmiotowy i przedmiotowy systemu a jego finansowanie}

Do najistotniejszych z punktu widzenia świadczeniobiorców zadań władzy publicznej należy finansowanie (w trybie i na zasadach określonych ustawą) określonych świadczeń opieki zdrowotnej. Kwestie te reguluje art. 97 u.ś.o.z. określający zakres działania Funduszu, wskazujący jednak w ustępie 8, że NFZ otrzymuje z budżetu państwa dotację na sfinansowanie kosztów realizacji niektórych zadań. Oznacza to, że zadaniem NFZ jest w istocie zorganizowanie dostępu do świadczeń opieki zdrowotnej określonego rodzaju lub możliwości skorzystania z nich zdefiniowanym w ustawie grupom podmiotów (poprzez czynności organizacyjne: zawieranie i rozliczanie umów o udzielanie świadczeń opieki zdrowotnej), natomiast ciężar ich sfinansowania ponosi budżet - nie obciążają one zatem funduszu pochodzącego ze „składek" na „ubezpieczenie zdrowotne"10. Finansowanie świadczeń przez władze publiczne odbywa się zatem pośrednio, dotują one NFZ nie opłacając samodzielnie świadczeniodawców.

"Zaopatrzeniowe" finansowanie wynika przede wszystkim z faktu "zaopatrzeniowości" tytułu do świadczeń. Artykuł 13 u.ś.o.z. stanowi, że (z zastrzeżeniem przepisów odrębnych) świadczenia opieki zdrowotnej udzielane świadczeniobiorcom innym niż ubezpieczeni są finansowane $z$ budżetu państwa. $W$ tym kontekście należy przywołać przepis art. 2 u.ś.o.z., zgodnie z którym prawo do korzystania ze świadczeń opieki zdrowotnej finansowanych ze środków publicznych na zasadach określonych w ustawie przysługuje świadczeniobiorcom. Ta zbiorcza kategoria obejmuje nie tylko osoby objęte powszechnym - obowiązkowym i dobrowolnym ubezpieczeniem zdrowotnym, czyli ubezpieczonych. Mimo że kazuistyczny katalog tytułów ubezpieczeniowych z art. 66 u.ś.o.z. jest niezwykle szeroki, ustawodawca świadomy był faktu, że nie obejmie on wszystkich obywateli, dlatego w art. 2 ust. 1 pkt $2-4$ wskazał grupy

10 Odrębnym zagadnieniem jest kwestia charakteru prawnego owej „składki”: zasada uniwersalności składki, brak instrumentów ograniczających jej wysokość, okoliczność, że obciążająca ubezpieczonego składka na ubezpieczenie zdrowotne i ustawowa gwarancja nie stanowią świadczeń wzajemnych, regulacja art. 81 ust. 6 u.ś.o.z., zgodnie z którą podstawę wymiaru składki na ubezpieczenie zdrowotne zatrudnionych pomniejsza się o kwoty składek na ubezpieczenia społeczne, prowadzą do wniosku, że „składka na ubezpieczenie zdrowotne” jest parapodatkową sui generis daniną publiczną. Por. D.E. Lach, Zasada równego dostępu do świadczeń opieki zdrowotnej, Wolters Kluwer, Warszawa 2011, s. 286-336; idem, Zasada równości a równy dostęp do świadczeń opieki zdrowotnej w aspekcie finansowym w kontekście składek na "ubezpieczenie zdrowotne", [w:] Z. Niedbała (red.), Prawo wobec dyskryminacji w życiu społecznym, gospodarczym i politycznym, Warszawa 2011; idem, Nabycie prawa do świadczeń opieki zdrowotnej, „Praca i Zabezpieczenie Społeczne” 2010, nr 11. 
podmiotów uprawnione do świadczeń, ale nie będące ubezpieczonymi, a zatem nieopłacające składek ${ }^{11}$. Z tego też względu zdecydował się na obciążenie kosztami udzielanych im świadczeń fiskusa. Chodzi tu przede wszystkim o osoby najuboższe, co do zasady pozbawione stałych źródeł dochodu, zagrożone wykluczeniem społecznym. Na mocy art. 2 ust. 1 pkt 2 u.ś.o.z. świadczeniobiorcami są bowiem także „inne niż ubezpieczeni osoby posiadające miejsce zamieszkania na terytorium Rzeczypospolitej Polskiej, które posiadają obywatelstwo polskie lub uzyskały w Rzeczypospolitej Polskiej status uchodźcy lub ochronę uzupełniająca, lub zezwolenie na pobyt czasowy udzielone w związku z okolicznościa, o której mowa w art. 159 ust. 1 pkt 1 lit. c lub d ustawy z dnia 12 grudnia 2013 r. o cudzoziemcach ${ }^{12}$, [...] spełniające kryterium dochodowe, o którym mowa w art. 8 ustawy z dnia 12 marca 2004 r. o pomocy społecznej ${ }^{13}$, [...] co do których nie stwierdzono okoliczności, o której mowa w art. 12 tej ustawy", na zasadach i w zakresie określonych dla ubezpieczonych. Mając niewątpliwe na uwadze treść art. 68 ust. 3 Konstytucji, który stanowi, że władze publiczne są obowiązane do zapewnienia szczególnej opieki zdrowotnej m.in. dzieciom i kobietom ciężarnym, do grona świadczeniobiorców włączono także „,inne niż wymienione w pkt. 1 i 2 osoby, które nie ukończyły 18. roku życia posiadające obywatelstwo polskie lub które uzyskały w Rzeczypospolitej Polskiej status uchodźcy lub ochronę uzupełniającą lub zezwolenie na pobyt czasowy udzielone w związku z okolicznością, o której mowa w art. 159 ust. 1 pkt 1 lit. c lub d ustawy z dnia 12 grudnia 2013 r. o cudzoziemcach, posiadające miejsce zamieszkania na terytorium Rzeczypospolitej Polskiej (art. 2 ust. 1 pkt 3 u.ś.o.z.) [oraz] inne niż wymienione $\mathrm{w}$ pkt. 1-3 osoby posiadające miejsce zamieszkania na terytorium Rzeczypospolitej Polskiej, które są w okresie ciąży, porodu lub połogu posiadające obywatelstwo polskie lub które uzyskały w Rzeczypospolitej Polskiej status uchodźcy lub ochronę uzupełniająca, lub zezwolenie na pobyt czasowy udzielone w związku z okolicznościa, o której mowa w art. 159 ust. 1 pkt 1 lit. c lub d ustawy z dnia 12 grudnia 2013 r. o cudzoziemcach" (art. 2 ust. 1 pkt 4 u.ś.o.z.).

Fiskus ponosi koszty udzielanych im świadczeń na podstawie art. 97 ust. 8 w związku z art. 97 ust. 3 pkt 2a i 3 u.ś.o.z.

Wskazać trzeba także na budżetowe finansowanie świadczeń dla podmiotów, którym, niezależnie od ewentualnej gwarancji ubezpieczeniowej, przepisy szczególne zapewniają prawo do świadczeń zdrowotnych czy też świadczeń opieki zdrowotnej poza systemem, na specjalnych wa-

${ }^{11}$ Co do problematyki zróżnicowanego obciążenia składką poszczególnych grup ubezpieczonych por. D.E. Lach, Zasada równego dostępu..., s. 324-336.

12 DzU, 2013, poz. 1650 oraz z 2014 r., poz. 463.

${ }^{13}$ DzU, 2013, poz. 182, ze zm. 5. 
runkach. Chodzi tu w pierwszym rzędzie o kwestie zdrowia publicznego $^{14}$, wskazać jednak trzeba także szczególne uprawnienie do świadczeń dla posiadaczy Karty Polaka ${ }^{15}$ (art. 97 ust. 8 w związku z art. 97 ust. 3 pkt 2a u.ś.o.z.).

Z drugiej strony finansowanie budżetowe dotyczy także wybranych rodzajów świadczeń. Przede wszystkim chodzi tu o świadczenia wysokospecjalistyczne, tj. takie świadczenia opieki zdrowotnej lub procedury medyczne, które spełniają łącznie dwa kryteria: udzielenie świadczenia wymaga wysokiego poziomu zaawansowania technicznego świadczeniodawcy i zaawansowanych umiejętności osób udzielających świadczenia, koszt jednostkowy świadczenia jest wysoki (art. 5 pkt 39 u.ś.o.z.) ${ }^{16}$, finansowane na podstawie art. 97 ust. $8 \mathrm{w}$ związku z art. 97 ust. 3 pkt $2 \mathrm{~b}$ u.ś.o.z. Nie bez znaczenia, w kontekście obowiązku zapewnienia równego dostępu do świadczeń opieki zdrowotnej i katalogu świadczeń gwarantowanych, jest także obowiązek sfinansowania przez fiskusa świadczeń opieki zdrowotnej udzielonych osobom skierowanym do przeprowadzenia poza granicami kraju leczenia lub badań diagnostycznych, należących do świadczeń gwarantowanych, których aktualnie nie wykonuje się w kraju (art. 97 ust. 8 w związku z art. 97 ust. 3 pkt 3b u.ś.o.z.).

Trzeba przy tym podnieść, że zgodnie z planem finansowym NFZ na 2015 r. ${ }^{17}$ dotacje $\mathrm{z}$ budżetu państwa na finansowanie zadań, o których mowa w art. 97 ust. 3 pkt 2a, 3 i 3b u.ś.o.z. wyniosą łącznie 151 milionów 485 tysięcy złotych, co stanowi jedynie ok. 0,22\% przychodu NFZ (wobec planowanych przychodów ze składek na poziomie 66 miliardów $851 \mathrm{mi}-$ lionów 829 tysięcy złotych). Ponieważ nowe reguły dotyczące finansowania świadczeń wysokospecjalistycznych obowiązują dopiero od 1 stycznia $2015 \mathrm{r} .{ }^{18}$ dotacja $z$ tego tytułu nie została jeszcze ujęta w planie finansowym. Z planu budżetu na rok $2015^{19}$ można jednak ustalić, że planowana kwota

${ }^{14}$ Leczenie osób uzależnionych od alkoholu (ustawa z dnia 26 października 1982 r. o wychowaniu w trzeźwości i przeciwdziałaniu alkoholizmowi), osób uzależnionych od narkotyków (ustawa z dnia 29 lipca 2005 r. o przeciwdziałaniu narkomanii), osób chorych psychicznie (ustawa z dnia 19 sierpnia $1994 \mathrm{r}$. o ochronie zdrowia psychicznego) oraz osób chorych zakaźnie - w przypadku świadczeń zdrowotnych związanych ze zwalczaniem chorób, zakażeń i chorób zakaźnych (ustawa z dnia 5 grudnia 2008 r. o zapobieganiu oraz zwalczaniu zakażeń i chorób zakaźnych u ludzi).

15 Ustawa z dnia 7 września 2007 r. o Karcie Polaka.

${ }^{16}$ Chodzi tu o świadczenia z zakresu transplantologii i kardiochirurgii (także dziecięcej).

17 http://www.nfz.gov.pl/new/?katnr=3\&dzialnr=10\&artnr=6248.

18 Ustawa z dnia 22.07.2014 r. (DzU, 2014, poz. 1138). Wcześniej umowy o udzielanie tych świadczeń były zawierane bezpośrednio przez ministra zdrowia.

19 http://www.mf.gov.pl/ministerstwo-finansow/dzialalnosc/finanse-publiczne/ budzet-panstwa/ustawy-budzetowe/2015/projekty-ustawy/-/asset_publisher/UUv1/ content/projekt-zatwierdzony-przez-rade-ministrow-w-dniu-24-wrzesnia-2014-r-usta 
dotacji wynosi 1 miliard 518 milionów 457 tysięcy złotych. W stosunku do planowanych przez NFZ kosztów leczenia szpitalnego (28 miliardów 441 milionów 93 tysiące złotych) udział środków budżetowych jest zatem wyższy, ale nadal wynosi tylko niewiele ponad 5\% tych kosztów.

\section{Prawotwórcze i nadzorcze zadania władzy publicznej a dopuszczalność konstruowania roszczenia o świadczenie przeciwko władzy publicznej}

Jak już wyżej zauważono ustawodawca, powołując do życia NFZ, jako powierniczego zarządcę i organizatora systemu, kierował się, jak się wydaje, przede wszystkim chęcią wykluczenia ryzyka konstruowania (dochodzenia) przez świadczeniodawców jakichkolwiek roszczeń z tytułu umów o udzielanie świadczeń opieki zdrowotnej (lub ich bezumownego udzielania - np. w odniesieniu do świadczeń ponad- lub pozalimitowych) od Skarbu Państwa. Także pozycja świadczeniobiorców została uregulowana niekorzystnie $\mathrm{w}$ stosunku do ubezpieczonych $\mathrm{w}$ technice ubezpieczeniowej: nie przysługuje im wobec powiernika żadne roszczenie o spełnienie świadczenia. Mając zaś na uwadze, że władza publiczna - powierzający - zobowiązana jest jedynie do zapewnienia równego dostępu do świadczeń opieki zdrowotnej, przy czym warunki i zakres udzielanych świadczeń określa ustawa (art. 68 ust. 2 Konstytucji), to beneficjentom nie przysługują także żadne roszczenia o spełnienie / sfinansowanie określonych świadczeń w stosunku do powierzającego. Problematyczne może być także konstruowanie skargi konstytucyjnej opartej na naruszeniu minimum obowiązków władzy publicznej zdefiniowanych w art. 68 ust. 2 Konstytucji wobec faktu, że z przepisu tego wyinterpretowuje się jedynie normę programową o strukturze nakazu optymalizacyjnego ${ }^{20}$.

Tym niemniej przedmiotem oceny Trybunału Konstytucyjnego mogłyby być obowiązki negatywne dotyczące powstrzymania się od ingerencji w minimum wynikające z treści art. 68 ust. 2 Konstytucji, a zatem kwestia, czy zastosowane rozwiązania utrudniają lub uniemożliwiają obywatelom dostęp do świadczeń opieki zdrowotnej, względnie w sposób nieuzasadniony ten dostęp różnicują. Dopuszczalna byłaby zatem skarga konstytucyjna dotycząca żądania stwierdzenia niezgodności z Konstytucją aktu,

wy-budzetowej-na-rok-2015-przekazany-do-sejmu-rp?redirect=http $\% 3 \mathrm{~A} \% 2 \mathrm{~F} \% 2 \mathrm{Fwww}$. mf.gov.pl\%2Fministerstwo-finansow\%2Fdzialalnosc\%2Ffinanse-publiczne $\% 2$ Fbudzet-panstwa\%2Fustawy-budzetowe\%2F2015\%2Fprojekty-ustawy\%3Fp_p_id\%3D101_INSTANCE_ UUv1\%26p_p_lifecycle\%3D0\%26p_p_state\%3Dnormal\%26p_p_mode\%3Dview\%26p_p_ col_id\%3Dcolumn-2\%26p_p_col_count\%3D1\#p_p_id_101_INSTANCE_UUv1_.

${ }^{20}$ Por. D.E. Lach, Zasada równego dostępu..., s. 23-34. 
na podstawie którego wydano orzeczenie sądu lub organu w indywidualnej sprawie, skutkiem czego doszło do bezzasadnego uniemożliwienia bądź zróżnicowania dostępu do świadczeń opieki zdrowotnej ${ }^{21}$.

W tym kontekście należy jednak przywołać orzeczenie niemieckiego trybunału konstytucyjnego (Bundesverfassungsgericht - BVerfG), które odbiło się szerokim echem $\mathrm{w}$ doktrynie niemieckiej ${ }^{22}$. W uchwale $\mathrm{z}$ dnia 6 grudnia 2005 r., 1 BvR 347/98, trybunał uznał, że niezgodne $\mathrm{z}$ art. 2 ust. $1^{23}$ niemieckiej konstytucji w związku z zasadą państwa socjalnego ${ }^{24}$ i z art. 2 ust. 2 zdanie $1^{25}$ niemieckiej konstytucji jest pozbawienie osoby ubezpieczonej zdrowotnie prawa do wybranego przez nią świadczenia, gdy w odniesieniu do zagrażającej jej życiu lub zasadniczo śmiertelnej choroby nie stoi do dyspozycji powszechnie uznane i odpowiadające standardom medycznym świadczenie zdrowotne a zastosowanie wybranego przez ubezpieczonego świadczenia rokuje wyzdrowieniem lub odczuwalnym pozytywnym wpływem na przebieg choroby ${ }^{26}$. Sama teza nie jest jednak tak istotna, jak uzasadnienie uchwały, w którym trybunał nawiązał nie tylko do prawa do życia i zasady państwa socjalnego, ale przywołał wprost przepis $\S 5 \mathrm{~V}$ księgi kodeksu socjalnego (ubezpieczenie chorobowe / zdrowotne), zawierający katalog tytułów ubezpieczeniowych. Bundesverfassungsgericht stwierdził, że narusza te przepisy nałożenie na daną osobę obowiązku ubezpieczeniowego i składkowego związanego

${ }^{21}$ Por. D.E. Lach, Kilka uwag w przedmiocie środków prawnych stużących świadczeniobiorcom opieki zdrowotnej w sytuacji faktycznej dyskryminacji, [w:] B. Cudowski, J. Iwulski (red.), $Z$ aktualnych zagadnień prawa pracy i zabezpieczenia społecznego. Księga Jubileuszowa Profesora Waleriana Sanetry, Białystok 2013.

${ }^{22}$ Por. U. Becker, Das Recht auf Gesundheitsleistungen, [w:] G. Manssen, M. Jachmann, Ch. Gröpl, Nach geltendem Verfassungsrecht - Festschrift für Udo Steiner zum 70. Geburtstag, Stuttgart 2009, s. 50-76 i tam wskazana literatura.

${ }_{23}$ „Każdy ma prawo do wolnego rozwoju własnej osobowości, o ile nie narusza to praw innych osób i o ile nie narusza to porządku konstytucyjnego lub zasad moralności”. „Jeder hat das Recht auf die freie Entfaltung seiner Persönlichkeit, soweit er nicht die Rechte anderer verletzt und nicht gegen die verfassungsmäßige Ordnung oder das Sittengesetz verstößt".

${ }^{24}$ Art. 20 ust. 1 „Republika Federalna Niemiec jest demokratycznym i socjalnym państwem federalnym”. „Die Bundesrepublik Deutschland ist ein demokratischer und sozialer Bundesstaat".

${ }^{25}$ „Każdy ma prawo do życia i nienaruszalności cielesnej”. „Jeder hat das Recht auf Leben und körperliche Unversehrtheit".

${ }^{26}$ Es ist mit den Grundrechten aus Art. 2 Abs. 1 GG in Verbindung mit dem Sozialstaatsprinzip und aus Art. 2 Abs. 2 Satz 1 GG nicht vereinbar, einen gesetzlich Krankenversicherten, für dessen lebensbedrohliche oder regelmäßig tödliche Erkrankung eine allgemein anerkannte, medizinischem Standard entsprechende Behandlung nicht zur Verfügung steht, von der Leistung einer von ihm gewählten, ärztlich angewandten Behandlungsmethode auszuschließen, wenn eine nicht ganz entfernt liegende Aussicht auf Heilung oder auf eine spürbare positive Einwirkung auf den Krankheitsverlauf besteht. 
z przyznaniem gwarancji świadczenia opieki zdrowotnej i jednocześnie wyłączenie (wykluczenie) tej osoby z systemu i zmuszenie jej do poszukiwania opieki zdrowotnej na własny koszt i poza systemem w sytuacji, gdy brak jest powszechnie uznanego i odpowiadającego standardom medycznym świadczenia zdrowotnego odpowiedniego dla zagrażającej życiu tej osoby lub zasadniczo śmiertelnej choroby. Uznał bowiem, że państwo tworząc system opieki zdrowotnej przejmuje odpowiedzialność za życie i nienaruszalność cielesną ubezpieczonych (w odniesieniu do systemu polskiego - świadczeniobiorców - D.E.L.), a zatem zapewnienie opieki w przypadkach chorób zagrażających życiu lub zasadniczo śmiertelnych należy do minimum / sedna (niem. Kernbereich) obowiązku świadczeniowego i wymaganego na podstawie art. 2 ust. 2 zdanie 1 niemieckiej konstytucji minimalnego poziomu opieki ${ }^{27}$.

W literaturze niemieckiej podnoszono, że nie ma przy tym znaczenia, jaką formę ukształtowania systemu świadczeniowego wybierze ustawodawca - prawo do życia określa minimum systemowej ochrony. Tym samym z jednej strony umożliwia konstruowanie podmiotowego prawa do świadczenia opieki zdrowotnej, z drugiej jednak strony ogranicza je do sytuacji - jak ujął to trybunał - chorób zagrażających życiu lub zasadniczo śmiertelnych ${ }^{28}$. Najistotniejsze jest jednak to, że przełamano dotychczasowe rozumienie norm konstytucyjnych jako nakazujących jedynie stworzenie określonego systemu opieki zdrowotnej i zagwarantowanie obywatelom dostępu do świadczeń abstrakcyjnie rozumianej opieki $\mathrm{w}$ jego ramach i wyinterpretowano z nich obowiązek zapewniania określonych świadczeń $\mathrm{w}$ odniesieniu do potrzeby zindywidualizowanego uprawnionego, z zastrzeżeniem jednak charakteru choroby ${ }^{29}$.

Podkreślenia wymaga, że Bundesverfassungsgericht oparł się przy tym na ogólnym prawie do życia i zasadach państwa socjalnego wobec braku w niemieckiej konstytucji konkretniej zdefiniowanych praw socjalnych. Mając jednak na uwadze treść art. 68 Konstytucji RP tym bardziej można wyobrazić sobie konstruowanie podmiotowego prawa do skonkretyzowanych świadczeń opieki zdrowotnej wobec władzy publicznej.

\section{Ustawowe a faktyczne znaczenie władzy publicznej}

Pod koniec 2014 r., jak niemalże co roku, media śledziły zamieszanie wokół umów o udzielanie świadczeń podstawowej opieki zdrowotnej. Należy przypomnieć, że zgodnie z art. 159 u.ś.o.z. umowy te zawiera się

${ }^{27}$ Ustępy 64 i 65 uzasadnienia.

${ }^{28}$ Por. U. Becker, Das Recht..., s. 66-67.

${ }^{29}$ Ibidem, s. 69-72. 
ze świadczeniodawcami "spełniającymi warunki do zawarcia umowy określone przez Prezesa Funduszu" a przepisy dotyczące konkursu ofert i rokowań są wyraźnie wyłączone. Innymi słowy NFZ dyktuje warun$\mathrm{ki}$, a świadczeniodawcy - wobec ograniczonego rynku prywatnego - są $\mathrm{w}$ istocie skazani na zaproponowane im umowy. Być może w przyszłości relacje między NFZ a świadczeniodawcami zostaną uregulowane inaczej, de lege lata jednak brak jest instytucjonalnych rozwiązań podobnych choćby niemieckiemu prawu świadczeniodawców (niem. Leistungserbringungsrecht $)^{30}$. Nie zmienia to faktu, że stronami umowy są świadczeniodawca i NFZ. Tymczasem negocjacje toczone były przez ministra zdrowia z jednej i grupę lekarzy z drugiej strony, przy czym lekarze ci występowali w ramach Federacji Związków Pracodawców Ochrony Zdrowia, a zatem podmiotu pomyślanego $\mathrm{w}$ zupełnie innym celu ${ }^{31}$ niż prowadzenie (i to tylko w imieniu części środowiska) negocjacji z organizatorem systemu opieki zdrowotnej. Brak właściwej regulacji zastąpiły zatem półśrodki. Z punktu widzenia niniejszego opracowania należy jednak zwrócić uwagę na okoliczność, że - w istocie bez umocowania ustawowego i wbrew kształtowi systemu - władza wykonawcza przejęła obowiązki organizatora systemu, który w toczonych rozmowach nie brał nawet udziału, zepchnięty do roli wykonawcy ministerialnych instrukcji.

Sytuacja ta współgra z powszechnym społecznym przekonaniem, widocznym także w wypowiedziach polityków i mediów, że służba zdrowia nadal istnieje, a każdy ma prawo do bezpłatnej opieki zdrowotnej, przy czym władza publiczna jest zobowiązana do zagwarantowania tej opieki i odpowiada za wszelkie niedogodności w tym względzie, dotyczące kolejek, refundowania leków, stanu i wyposażenia szpitali, wynagrodzeń personelu medycznego itd. Być może należałoby zatem zerwać z powierniczą fikcją i powrócić do stricte zaopatrzeniowych rozwiązań organizacyjno-finansowych. Nie można się jednak oprzeć wrażeniu, że płonne byłyby oczekiwania poprawy dostępności opieki zdrowotnej po dokonaniu takiej zmiany.

${ }^{30}$ Por. D.E. Lach, Stosunki prawne między instytucja ubezpieczenia zdrowotnego a świadczeniodawcami w Niemczech $i$ w Polsce, „Ruch Prawniczy, Ekonomiczny i Socjologiczny” 2005, nr 4.

31 Zgodnie z art. 5 ustawy z 23.05.1991 r. o organizacjach pracodawców (DzU, 1991, nr 55, poz. 235 ze zm.) podstawowym zadaniem związków pracodawców, ich federacji i konfederacji jest ochrona praw i reprezentowanie interesów, w tym gospodarczych, zrzeszonych członków wobec związków zawodowych, organów władzy i administracji rządowej oraz organów samorządu terytorialnego. 


\section{Zakończenie}

Zadania władz publicznych w odniesieniu do systemu opieki zdrowotnej nie ograniczają się jedynie do zadań prawotwórczych i ewaluacyjnych. Podkreślenia wymaga, że fiskus ponosi część kosztów finansowania systemu. I chociaż jest to niewielki ułamek tych kosztów, to przejęcie finansowania świadczeń wysokospecjalistycznych ma, z uwagi na ich charakter, istotne znaczenie. Mając na uwadze tematykę niniejszej księgi można zauważyć, że zarówno oczekiwania społeczne, jak i uwzględniająca je ewolucja regulacji prawnej, zdają się zmierzać w kierunku zwiększenia znaczenia władzy publicznej nie tylko, gdy idzie o finansowanie, ale i o organizację systemu opieki zdrowotnej. (Od)tworzenie „służby zdrowia" staje się programem politycznym ${ }^{32}$. Jak zresztą pokazują negocjacje lekarzy z ministrem zdrowia coraz częściej wyodrębnieniu NFZ przypisuje się jedynie formalny charakter. Ponieważ, jak wskazano wyżej, możliwe wydaje się także konstruowanie roszczenia o zindywidualizowane świadczenie opieki zdrowotnej przeciwko władzy publicznej, można się zastanawiać, czy przyszłością systemu opieki zdrowotnej nie będzie jego (ponowne) „upaństwowienie”.

\section{Bibliografia}

Baka K., Machulak G., Pietraszewska-Macheta A., Sidorko A., Ustawa o świadczeniach opieki zdrowotnej finansowanych ze środków publicznych. Komentarz, Warszawa 2010.

Becker U., Das Recht auf Gesundheitsleistungen, [w:] G. Manssen, M. Jachmann, Ch. Gröpl, Nach geltendem Verfassungsrecht - Festschrift für Udo Steiner zum 70. Geburtstag, Stuttgart 2009.

Biernat S., Prywatyzacja zadań publicznych. Problematyka prawna, Warszawa-Kraków 1994.

Doliwa A., Ustawowe powiernictwo wykonywania własności państwowej na przykładzie Agencji Własności Rolnej Skarbu Państwa, „Studnia Prawnicze” 2003, nr 1.

Jończyk J., Czwarta wersja powszechnego ubezpieczenia zdrowotnego, „Praca i Zabezpieczenie Społeczne" 2004, nr 11.

Jończyk J., Prawo zabezpieczenia społecznego, Kraków 2001

Jończyk J., Ubezpieczenie zdrowotne, „Praca i Zabezpieczenie Społeczne” 2003, nr 4.

Lach D.E., Kilka uwag w przedmiocie środków prawnych służacych świadczeniobiorcom opieki zdrowotnej w sytuacji faktycznej dyskryminacji, [w:] B. Cudowski, J. Iwulski (red.), Z aktualnych zagadnień prawa pracy i zabezpieczenia społecznego. Ksiega Jubileuszowa Profesora Waleriana Sanetry, Białystok 2013.

Lach D.E., Nabycie prawa do świadczeń opieki zdrowotnej, „Praca i Zabezpieczenie Społeczne” 2010, nr 11 .

${ }^{32} \mathrm{~W}$ programie politycznym największej obecnie partii opozycyjnej - PiS - wskazano na konieczność likwidacji NFZ, zmianę finansowania systemu na budżetowy oraz przekazanie obowiązków płatników wojewodom, por. www.pis.org.pl/download.php?g=mmedia\&f=program_pis_2014.pdf. 
Lach D.E., Powiernicza technika realizacji zabezpieczenia społecznego (na przykładzie ubezpieczenia zdrowotnego), „Państwo i Prawo” 2009, nr 3.

Lach D.E., Powierzanie realizacji zadań publicznych z zakresu zabezpieczenia społecznego podmiotom niepublicznym, „Państwo i Prawo” 2015, nr 2.

Lach D.E., Prawny paradygmat opieki zdrowotnej a stosunek "ubezpieczenia zdrowotnego" i jego charakter prawny, [w:] Z. Kubot, T, Kuczyński (red.), Z zagadnień prawa pracy i prawa socjalnego. Księga jubileuszowa Profesora Herberta Szurgacza, Wrocław 2011.

Lach D.E., Stosunki prawne między instytucja ubezpieczenia zdrowotnego a świadczeniodawcami w Niemczech i w Polsce, „Ruch Prawniczy, Ekonomiczny i Socjologiczny” 2005, nr 4.

Lach D.E., Zasada równego dostępu do świadczeń opieki zdrowotnej, Wolters Kluwer, Warszawa 2011.

Lach D.E., Zasada równości a równy dostęp do świadczeń opieki zdrowotnej aspekcie finansowym w kontekście składek na "ubezpieczenie zdrowotne”, [w:] Z. Niedbała (red.), Prawo wobec dyskryminacji w życiu społecznym, gospodarczym i politycznym, Warszawa 2011.

Szurgacz H., Zagadnienie przekazywania przez państwo zadań w zakresie zabezpieczenia społecznego podmiotom niepublicznym, [w:] H. Szurgacz (red.), Konstytucyjne problemy prawa pracy i zabezpieczenia społecznego. Referaty na XV Zjazd Katedr i Zakładów Prawa Pracy i Ubezpieczeń Społecznych, Wrocław 1-2 czerwca 2005 r., Wrocław 2005.

Włodarczyk W.C., Reforma opieki zdrowotnej w Polsce, Studium polityki zdrowotnej, Kraków 1998.

\section{Public Authorities versus Public Health Care System}

\section{Summary}

The subject of this chapter is the relationship between public authorities and the system of the health care. Author discusses the legal character of the Polish "health insurance" as a form of trust, and against this background describes the role and duties of the public authorities. It has been presented the question of the financing of the system connected to circle of its beneficiaries and benefits and services' scope. Author considers also the admissibility of constructing a claim for benefit against public authority taking into account the lawmaking and supervisory duties of public authorities. 